\title{
Two New E Colicins, E8 and E9, Produced by a Strain of Escherichia coli
}

\author{
By PEARL C. COOPER* AND RICHARD JAMES \\ School of Biological Sciences, University of East Anglia, Norwich NR4 7TJ, UK
}

(Received 21 June 1983)

\begin{abstract}
We have isolated a strain of Escherichia coli from chicken caeca which produces two E colicins and colicin M. This strain has seven plasmids, five of which have been transferred to E. coli K12. Two $E$. coli $\mathrm{K} 12$ derivatives which produce the two $\mathrm{E}$ colicins separately have been tested against seven standard $E$ colicin producing strains which define seven different immunity groups. Our results indicate that these new E colicins define two further immunity groups, E8 and E9.
\end{abstract}

\section{INTRODUCTION}

Colicins are plasmid-determined antibiotic proteins which are produced by some strains of enterobacteria and are active on strains of Escherichia coli. We screened strains of enterobacteria isolated from chickens for colicin production and found one, E. coli strain J, which had colicin $\mathrm{E}$ and colicin $\mathbf{M}$ activities. E colicins are those which require the $b t u B$ gene product for adsorption (this gene product is also used for adsorption of phage BF-23 and uptake of vitamin B12) and are inactive on $b t u B$ mutants. Colicin $M$ uses the ton $A$ gene product, also used by phage $\phi 80$, and is inactive on ton $A$ mutants.

E colicins are further classified into immunity groups on the basis of their activity on other colicin producing, $b t u B^{+}$strains. If inactive on an E-colicin producer it is placed in the same immunity group. If active on a producer, it is placed in a separate immunity group. Thus far seven different E colicin immunity groups have been reported (see Males \& Stocker, 1982). Genetic analysis of strain $\mathbf{J}$ showed that it produces two $\mathbf{E}$ colicins. Immunity testing between derivatives producing each of these $E$ colicins separately and strains representing the colicin $E$ immunity groups E1 to E7 indicate that the E colicins of strain $J$ define two further immunity groups, E8 and E9.

\section{METHODS}

Bacterial strains and bacteriophages. These are shown in Table 1.

Media. Oxoid Nutrient Agar and Nutrient Broth were used for routine culturing and for colicin testing. Minimal medium was $\mathrm{M} 9$ (Miller, 1972) supplemented with L-amino acids $\left(20 \mu \mathrm{g} \mathrm{ml}^{-1}\right)$ as required, glucose $(0 \cdot 2 \%, \mathrm{w} / \mathrm{v})$, raffinose (filter-sterilized $0.5 \%, \mathrm{w} / \mathrm{v}$ ). Tetracycline was used at $10 \mu \mathrm{g} \mathrm{ml}^{-1}$, nalidixic acid at $25 \mu \mathrm{g} \mathrm{ml}^{-1}$, and streptomycin at $100 \mu \mathrm{g} \mathrm{ml}^{-1}$.

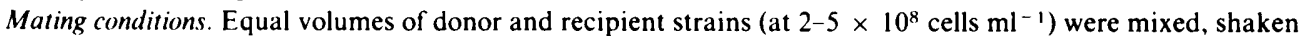
slowly at $37^{\circ} \mathrm{C}$ for $2-4 \mathrm{~h}$ and then plated directly on selective media. Trypsin, when used to inactivate colicin in the mating mixture, was added to $300 \mu \mathrm{g} \mathrm{ml}^{-1}$.

Colicin testing. The stab/overlayer method was used. Presumptive colicinogenic strains were stabbed into nutrient plates and incubated overnight at $37^{\circ} \mathrm{C}$. The plates were exposed to chloroform vapour, and overlayered with $2.5 \mathrm{ml}$ Davis agar (in distilled water) containing approximately $10^{7}$ bacteria. After overnight incubation plates were scored for zones of inhibition.

Plasmid preparation and electrophoresis. For agarose gel electrophoresis, plasmid DNA was prepared from $1 \mathrm{ml}$ of culture grown overnight in nutrient broth, using the alkaline lysis procedure of Birnboim \& Doly (1979), and electrophoresed overnight in $0.7 \%(\mathrm{w} / \mathrm{v})$ agarose in $0.04 \mathrm{M}$-Tris/acetate buffer pH 8.0 at $25 \mathrm{~V}$. For transformation, plasmid DNA was prepared by the 'small-scale' cleared lysate method of Hirsch et al. (1980) from 1 litre of cells grown at $37^{\circ} \mathrm{C}$. 
Table 1. Bacterial strains and phages

Strain designation J

JE5506

RJ179

PC264

PC639

PC640

CSH57

PC263

W3110

\begin{tabular}{|c|c|}
\hline A592 & tolA \\
\hline A593 & tolB \\
\hline Gllel & tolD \\
\hline PC259 & RJ179 (R64-11 drd $)^{*}$ \\
\hline PC620 & RJ (R64-11 drd) (ColEl-K 30)* \\
\hline PC621 & RJ179 (R64-11 drd) (ColE2-P9)* \\
\hline PC622 & RJ179 (R64-11 drd) (ColE3-CA-38)* \\
\hline PC252 & RJ179 (pPC101) (pPC104) \\
\hline PC617 & PC264 (pPC102) (pPC107) \\
\hline PC651 & $\mathrm{W} 3110(\mathrm{pPC101})$ \\
\hline PC652 & $\mathrm{W} 3110(\mathrm{pPCl} 102)$ \\
\hline PRC593 & W3110 (Col E1-K53) \\
\hline PRC594 & W3110 (ColE2-P9) \\
\hline PRC595 & W3110 (ColE3-CA38) \\
\hline PRC625 & W3110 (ColE4-CT9) \\
\hline PRC596 & W3110 (ColE5-099) \\
\hline PRC608 & W3110 (ColE6-CT14) \\
\hline PRC597 & W3110 (ColE7-K317) \\
\hline PRC499 & $\begin{array}{l}\text { Produces colicin B-K260; colicin B-r; } \\
\text { colicin M-r }\end{array}$ \\
\hline PRC628 & Produces colicin A-CA31 \\
\hline PC637 & PC264 (pPC107) \\
\hline PC650 & PC263 (pPC107) \\
\hline PC647 & Spontaneous $\phi 80$ vir-r mutant of PC637 \\
\hline BF 23 & $\begin{array}{l}\text { Phage using vitamin } \mathrm{B} 12 \text { receptor, btuB } \\
\text { gene product }\end{array}$ \\
\hline$\phi 80 v i r$ & $\begin{array}{l}\text { Phage using ferrichrome receptor, ton } A \\
\text { gene product }\end{array}$ \\
\hline
\end{tabular}

Source

Chicken caeca, Hall Farm, Hingham, UK

M. Inouye, SUNY, Stoneybrook, NY, USA

This laboratory

This laboratory

This laboratory

This laboratory

J. Miller, University of Geneva, Switzerland

This laboratory

Plasmid Reference Center, Stanford University, Calif., USA

B. Bachmann, Yale University, New Haven, Conn., USA

B. Bachmann

B. Bachmann

This laboratory

This laboratory

This laboratory

This laboratory

See text

See text

See text

See text

Plasmid Reference Center

Plasmid Reference Center

Plasmid Reference Center

Plasmid Reference Center

Plasmid Reference Center

Plasmid Reference Center

Plasmid Reference Center

Ruth Barker, Ninewells Hospital, Dundee, UK

R. Kadner, University of Virginia, Charlottesville, Va., USA

See text

See text

See text

R. Kadner

N. Murray, University of Edinburgh, UK

Abbreviations: s, sensitive; $r$, resistant; $\mathrm{Raf}^{+}$, raffinose utilization ; Tc, tetracycline; SM, streptomycin; Nal, nalidixic acid.

* Plasmid donors kindly supplied by Professor D. Sherratt, University of Glasgow, UK.

Transformation procedure. Strain W3110 was made competent for transformation by the method of Mandel \& Higa (1970) except that cells were washed with cold $0.1 \mathrm{M}-\mathrm{MgCl}_{2}$ prior to the $\mathrm{CaCl}_{2}$ wash. After mixing with plasmid DNA from PC252 or PC617, cells were plated on nutrient medium containing a colicin extract of the DNA donor strain. Survivors were screened for the production of the appropriate E colicin.

Preparation of colicin E3 antiserum. A crude colicin E3 extract was prepared from E. coli RJ179 ColE3-CA38 grown with shaking at $37^{\circ} \mathrm{C}$ in LB medium. At an $A_{550}$ of 0.2 , mitomycin C $\left(0.5 \mu \mathrm{g} \mathrm{ml}^{-1}\right)$ was added to 11 of culture. After incubation for a further $60 \mathrm{~min}$ the cells were harvested by centrifugation at $7000 \mathrm{~g}$ for $15 \mathrm{~min}$. The cell pellet was resuspended in $16 \mathrm{ml} 10 \mathrm{mM}$-phosphate buffer $\mathrm{pH} 7.0$ and was sonicated for four periods of $30 \mathrm{~s}$, with $60 \mathrm{~s}$ cooling in between, in an ice bath. The sonicated cells were centrifuged at $100000 \mathrm{~g}$ in a Beckman 65 
rotor for $\mathbf{4 0} \mathrm{min}$ to remove unbroken cells, cell membranes etc. and the supernatant was used as a crude colicin E3 extract to raise antiserum.

Two New Zealand White rabbits were injected at multiple sites on the back with $0.5 \mathrm{ml}$ colicin E3 extract (10 mg total protein) mixed with $0.5 \mathrm{ml}$ of Freund's complete adjuvant. At $14 \mathrm{~d}$ intervals the rabbits received booster intra-muscular injections of extract, mixed with incomplete Freund's adjuvant. After $42 \mathrm{~d}$ blood was removed from the ear vein of both rabbits and allowed to clot. After overnight incubation at $4{ }^{\circ} \mathrm{C}$ the serum was pooled and stored in portions at $-20^{\circ} \mathrm{C}$.

\section{RESULTS}

\section{Properties of strain $J$}

Strain $\mathbf{J}$ was isolated from chicken caeca. Colicin $\mathbf{E}$ and $\mathbf{M}$ activities were shown by the stab/overlayer method. Stab inoculation of strain $J$ gave a large zone (diameter, 12-15 mm) with a colicin E-sensitive indicator, a smaller zone with a colicin E-resistant, colicin M-sensitive indicator, and no zone with a colicin E-resistant, colicin M-resistant indicator. Strain $\mathbf{J}$ was found to be resistant to tetracycline and to ferment raffinose; raffinose also served as a sole source of carbon. Agarose gel electrophoresis of DNA isolated from strain $\mathbf{J}$ showed seven plasmid bands, called pPC101-pPC107 from smallest to largest (Fig. 1).

\section{Transfer of colicin E activity to E. coli $K 12$}

Strain $J$ was mated with RJ179, and plated on nalidixic acid to counterselect the donor. One of the few surviving recipient colonies was colicin $\mathrm{E}^{+}$, and agarose gel electrophoresis of DNA isolated from this strain (PC252) showed two plasmid bands, corresponding to pPC101 and pPC104 (data not shown). We assumed that the smaller plasmid was the colicin E plasmid by analogy with other colicin E plasmids, and that the larger was the mobilizing conjugative plasmid. Subsequent transformation of strain W3110 with DNA from this strain yielded an E colicin producing strain which carried pPC101 but not pPC104. We have not yet found a phenotypic character which is conferred by pPC104.

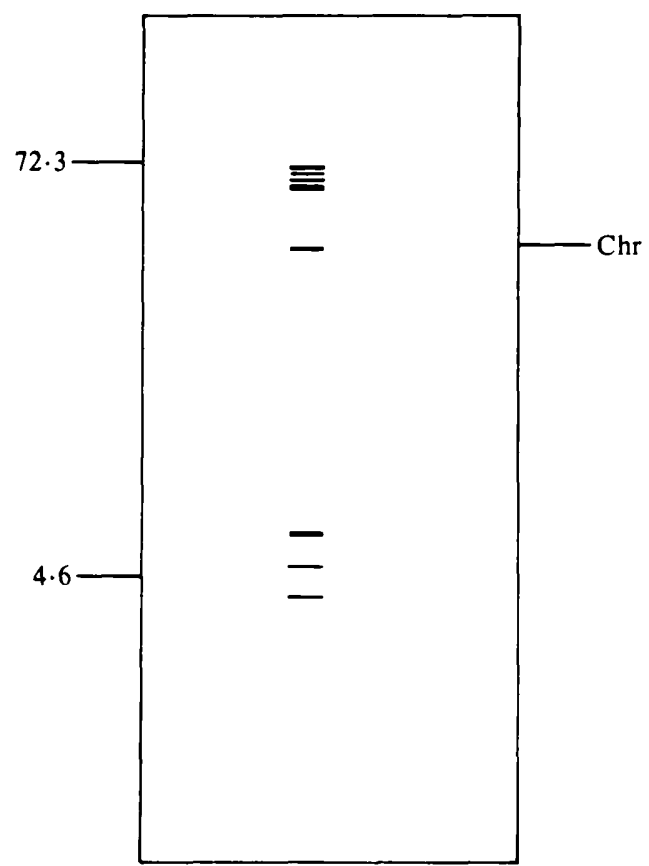

Fig. 1. Line drawing of an agarose gel preparation of the plasmids isolated from strain $\mathrm{J}$. The seven plasmid bands represent plasmids pPC101 (bottom) to pPC107 (top). The pointers indicate the positions of the molecular weight markers: ColE3-CA38, 4.6 MDal; R64-11, 72-3 MDal. Chr denotes chromosomal DNA. 
Table 2. Colicinogenic immunity between $\mathrm{ColE}^{+}$derivatives of $W 3110$

\begin{tabular}{|c|c|c|c|c|c|c|c|c|c|}
\hline \multirow{2}{*}{$\begin{array}{l}\text { Strains used as } \\
\text { indicators* }\end{array}$} & \multicolumn{9}{|c|}{ ColE plasmid carried by $\mathrm{W} 3110$} \\
\hline & E1-K53 & E2-P9 & E3-CA38 & E4-CT9 & E5-099 & E6-CT14 & E7-K 317 & pPC101 & $\mathrm{pPCl02}$ \\
\hline E1-K53 & - & + & + & + & + & + & + & + & + \\
\hline E2-P9 & + & - & + & + & + & + & + & + & + \\
\hline E3-CA38 & + & + & - & + & + & + & + & $(+)$ & + \\
\hline E4-CT9 & + & + & + & - & + & + & + & + & + \\
\hline E5-099 & + & + & + & + & - & + & + & + & + \\
\hline E6-CT14 & + & + & + & + & + & - & + & $(+)$ & + \\
\hline E7-K 317 & + & + & + & + & + & + & - & + & + \\
\hline $\mathrm{pPC} 101$ & + & + & + & + & + & + & + & - & + \\
\hline $\mathrm{pPC} 102$ & + & + & + & + & $(+)$ & + & + & + & - \\
\hline W3110 & + & + & + & + & + & + & + & + & + \\
\hline
\end{tabular}

Transfer of a second colicin $E$ activity from strain $J$

Conjugation experiments showed that $\mathrm{Raf}^{+}$, the ability to use raffinose as a sole source of carbon, could be transferred from strain $\mathrm{J}$ to PC264. This btuB recipient was used to avoid killing by $\mathrm{E}$ colicin in the mating mixture. We expected that the $\mathrm{Raf}^{+}$plasmid might mobilize pPC101 and screened $\mathrm{Raf}^{+}$progeny for colicin E activity. Of fourteen $\mathrm{Raf}^{+}$colonies tested, five were colicin $\mathrm{E}^{+}$. The $\mathrm{E}$ colicin of two of them was inactive against PC252 which carries pPC101, suggesting that these transconjugants also carried pPC101. The E colicin of the other three, however, was active against PC252, which placed it in a different immunity group. Agarose gel electrophoresis of $\mathrm{Raf}^{+}$colicin $\mathrm{E}^{+}$strains of the latter type, such as PC617, showed two plasmid bands which on the basis of mobility correspond to pPC102 and pPC107. pPC107 was the only plasmid observed on gels with $\mathrm{Raf}^{+}$colicin $\mathrm{E}^{-}$transconjugants indicating that it is the $\mathrm{Raf}^{+}$ plasmid and pPC102 is the second ColEplasmid. Transformation of W3110 with plasmid DNA from PC617 yielded colicin $\mathrm{E}^{+}$progeny carrying pPC102, but not pPC107.

\section{Immunity testing with standard ColE strains}

Strains PC651 and PC652 which are W3110 transformants carrying pPC101 and pPC102, respectively, were cross-tested against the seven standard colicin E producing strains (Table 2). All indicator strains were sensitive to the colicin produced by PC651, except the colicin E3 ${ }^{+}$and colicin $\mathrm{E}^{+}{ }^{+}$strains which were only partially sensitive. PC651 was sensitive to all E colicins tested. In the case of PC652, its E colicin was active on all other colicin $\mathrm{E}^{+}$indicators. PC652 was sensitive to all the E colicins except E5, to which it was only partially sensitive.

\section{Tests against colicin tolerant indicators}

Chromosomal mutants able to grow in the presence of $\mathrm{E}$ colicins but still $\mathrm{btuB}^{+}$are termed tolerant. TolA and tolD mutants are tolerant to colicins E2 and E3, but not to E1 ; tolB mutants are tolerant to all three (Bachmann \& Low, 1980). We therefore tested the tolerance of strains A592 (tolA), A593 (tolB), and Gllel (tolD) to all colicin $\mathrm{E}^{+}$strains including pPC651 and pPC652. A592 and Gllel were sensitive to colicin E1, but tolerant to all other E colicins. A593 was tolerant to all nine $\mathrm{E}$ colicins.

\section{Antigenic relatedness of $E$ colicins}

Antiserum prepared to colicin E3 extract was able to protect a sensitive strain against the killing activity of the colicin E3 ${ }^{+}$strain (Fig. 2). We found that this antiserum could also protect 


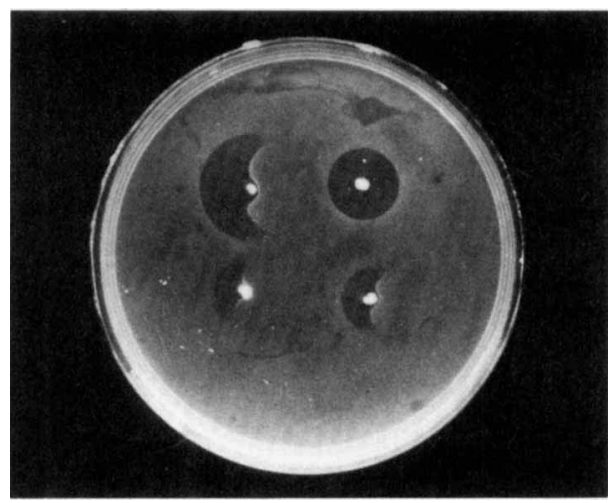

Fig. 2. The effect of antiserum to crude colicin E3 extract on the activity of various $E$ colicins. The stab/overlayer method was used, but before the $b t u \mathrm{~B}^{+}$indicator was overlayered, a $10 \mu \mathrm{l}$ drop of antiserum was applied to the right of each stab and allowed to soak in. Top left, PC651 (pPC101); top right, PRC593 (ColE1); bottom left, PRC595 (ColE3); bottom right, PRC608 (ColE6).

Table 3. Colicin production and immunity determined by plasmid pPC107

\begin{tabular}{cccccc} 
Indicator & \multicolumn{5}{c}{ Producer strain } \\
\cline { 2 - 6 } strain & PC637 & PC650 & PC647 & PRC499 & $\begin{array}{c}\text { Phage } \\
\text { P60 }\end{array}$ \\
PC264 & - & + & + & + & s \\
PC263 & - & - & - & + & r \\
PC637 & - & - & - & - & s \\
PC650 & - & - & - & - & r \\
PC647 & - & - & - & - & r \\
PRC499 & - & - & - & - & NT
\end{tabular}

NT, Not tested. + , Colicin zone; - , no colicin zone.

* Drop of phage suspension (approx. $10^{7}$ p.f.u. $\mathrm{ml}^{-1}$ ) applied to lawn. $\phi 80 \mathrm{vir}-\mathrm{s}=$ ton $A^{+}$and colicin $\mathrm{M}$ sensitive; $\phi 80 v i r-\mathrm{r}=$ ton $A$ and colicin M-resistant.

against the E colicins of PC651 and PC652. It also protected against all the E colicins of the standard strains except colicin E1. It did not protect against colicin A.

\section{Other properties of pPC107}

Transconjugants selected for $\mathrm{Raf}^{+}$and carrying pPC107 alone gave a colicin zone if they were ton $A$, lacking the colicin $\mathrm{M}$ receptor, but gave no zone if they were $\operatorname{ton}^{+}$(Table 3 ). This characteristic of colicin $M$ was reported by Fredricq \& Smarda (1970) who also found that colicin $B$ activity and colicin $M$ activity were usually determined by the same plasmid. We found that although transconjugants carrying pPC107 did not produce colicin B, they were completely immune to this colicin. A transmissible $\mathrm{Raf}^{+}$plasmid was described which also determines hydrogen sulphide production (Ørskov \& Ørskov, 1973). Neither strain J or E. coli K12 transconjugants carrying pPC107 produce $\mathrm{H}_{2} \mathrm{~S}$ in API 20E tests.

\section{Plasmid pPC105 carries tetracycline resistance and also mobilizes strain J ColE plasmids}

Selection for tetracycline-resistance $\left(\mathrm{Tc}^{\mathrm{r}}\right)$ transconjugants from a mating between strain $\mathrm{J}$ and RJ179 (in the presence of trypsin) yielded colicin $\mathrm{E}^{-}$and colicin $\mathrm{E}^{+}$colonies. The colicin $\mathrm{E}^{+}$colonies were of three classes when tested as producers against pPC101- and pPC102carrying indicator strains (Table 4). Classes 1 and 2 were active on one of the indicators, class 3 was active on both.

Plasmid DNA isolated from representative $\mathrm{Tc}^{r}$ transconjugants was electrophoresed on agarose gels. On the basis of relative mobilities, $\mathrm{Tc}^{r}$ colicin $\mathrm{E}^{-}$transconjugants carried $\mathrm{pPC} 105$ 
Table 4. Classes of colicin E producers among tetracycline-resistant transconjugants

The number of colonies is shown in parentheses.

\begin{tabular}{lcccc} 
& \multicolumn{3}{c}{ Stab culture } \\
& $\overbrace{\text { Class 1 (9) }}$ & Class 2 (1) & Class 3 (7) \\
pPC101 & - & + & + \\
,+ Clear zone of inhibition; &,- no zone of inhibition.
\end{tabular}

alone, class 1 colicin $\mathrm{E}^{+}$carried $\mathrm{pPC} 105$ and pPC101, class 2 colicin $\mathrm{E}^{+}$carried $\mathrm{pPC105}$ and pPC102; and class 3 carried pPC105, pPC101 and pPC102 (data not shown). This class was immune to both of the new E colicins. In separate experiments we also found that pPC104 and pPC105 could mobilize pPC101 and pPC102 together, as well as separately.

\section{DISCUSSION}

Strain J, a natural isolate of $E$. coli from chickens has seven plasmids, five of which have been transferred to $E$. coli $\mathrm{K} 12$. pPC101 and pPC102 are ColE plasmids with molecular weights of $6.7 \mathrm{~kb}$ and $7.8 \mathrm{~kb}$, respectively (R. James, unpublished) and are mobilized by the transmissible plasmids pPC104, pPC105 and pPC107. pPC107 confers tetracycline resistance and pPC107 confers raffinose utilization as well as colicin $\mathbf{M}$ production and immunity to colicins $\mathbf{B}$ and $\mathbf{M}$. Our major interest in strain $\mathrm{J}$ is the two $\mathrm{E}$ colicins it produces. We isolated transformants of $E$. coli strain W3110 which produce each of the new E colicins separately and tested them against the seven E-colicin type strains provided by the Plasmid Reference Center.

The E colicin of PC651 falls into a different immunity group from colicins E1, E2, E4, and E7 based on lack of cross-immunity. Both the colicin $\mathrm{E} 3^{+}$and $\mathrm{E} 6^{+}$strains are only partially sensitive to the colicin of PC651, giving smaller, turbid zones compared to the clear zones characteristic of lack of immunity. However, PC651 is fully sensitive to colicins E3 and E6, and the producers of these colicins are sensitive to each other's colicins. There are several possible explanations of these results. One is that colicin E3 immunity (and colicin E6 immunity) can protect to some extent against the colicin of PC651, but not vice versa. Another possibility is that the $\mathrm{ColE3}^{+}$and the ColE6 ${ }^{+}$strains carry a separate gene for immunity to the colicin of PC651 in addition to immunity to the colicin they produce.

Males \& Stocker (1980) described a strain of E. coli which produces only colicin E7 but is immune to colicin E7 and colicin E2. In this case immunity to colicin E2 was shown to be distinct from E7 immunity and determined by a separate plasmid, ColE $2_{\text {imm }}-\mathrm{K} 317$ (Watson et al., 1981).

Chak \& James (1984) have shown that in the case of the colicin E3 ${ }^{+}$strain PRC595, immunity to the colicin of PC651 is carried by ColE3-CA38 and is distinct from colicin E3 immunity. ColE3-CA38 has been cloned into pBR322 and this recombinant plasmid confers colicin E3 production and immunity to colicin E3 and the colicin of PC651. The latter immunity was abolished when transposons were inserted in one region of this plasmid without affecting colicin E3 production or immunity. The genetic basis of the immunity of the colicin $\mathrm{E}^{+}{ }^{+}$strain, PRC608, to the colicin of PC651 is being investigated.

We believe that the colicin of PC651 defines a new immunity group, E8. The colicin will be designated colicin E8-J. The E colicin of PC652, which is active on representatives of all seven standard colicin $\mathrm{E}^{+}$strains tested and PC651, defines a further immunity group, E9. The colicin of PC652 will be designated colicin E9-J. The partial immunity of this strain to colicin E5 may be due to a separate E5 immunity gene, and this possibility is being explored. Our limited studies show that E8-J and E9-J are similar to colicins E2 to E7 and different from colicin E1 on the basis of antigenicity and their activity on certain colicin-tolerant mutants. Mock \& Pugsley (1982) have reported antigenic similarities between colicins E2 to E7 by immunoprecipitation 
using antibody to purified colicin E3-CA38. It is not apparent why the E5 immunity of PC652 or the E8 immunity of ColE3-CA38 is only partial whereas the colicin B immunity of pPC107 is complete. Watson et al. (1981) noted that $\mathrm{E} 2$ immunity conferred by $\mathrm{Col} \mathrm{E} 2_{\mathrm{imm}}-\mathrm{K} 317$ is not completely effective in protecting indicator lawns from colicin E2 by the stab/overlayer method. Pugsley \& Reeves (1977) found that some colicin $\mathrm{B}^{+}$strains were also immune to colicins they did not produce, and occasionally this immunity was partial. Perhaps for certain plasmids immunity without production of the corresponding colicin is at a lower level than when colicin is produced. Strains carrying ColE8-J and ColE9-J will be deposited with the Plasmid Reference Center, Stanford University, Stanford, California 94305, USA.

We acknowledge the helpful suggestions of Professor B. A. D. Stocker, Drs Ruth Barker and Nahid Waleh. We thank Valerie Cossey for preparation of the manuscript. This work was supported by the Medical Research Council.

\section{REFERENCES}

BACHMANN, B. J. \& Low, K. B. (1980). Linkage map of Escherichia coli K-12, Edition 6. Microbiological Reviews 44, 1-56.

Birnboim, H. C. \& Doly, J. (1979). A rapid alkaline extraction procedure for screening plasmid DNA. Nucleic Acids Research 7, 1513-1523.

ChAK, K. F. \& JAMES, R. (1984). Localization and characterization of a gene on the ColE3-CA38 plasmid that confers immunity to colicin E8. Journal of General Microbiology 130 (in the Press).

FredericQ, P. \& SMarda, J. (1970). Complexité du facteur colicinogène B. Annales de l'Institut Pasteur 118, 767-774.

Hirsch, P. R., Van Montagu, M., Johnston, A. W B., Brewin, N. J. \& Schell, J. (1980). Physical identification of bacteriocinogenic, nodulation and other plasmids in strains of Rhizobium leguminosarum. Journal of General Microbiology 120, 403-412.

MALes, B. M. \& Stocker, B. A. D. (1980). Escherichia coli $\mathrm{K} 317$, formerly used to define colicin group E2, produces colicin E7, is immune to colicin E2, and carries a bacteriophage-restricting conjugative plasmid. Journal of Bacteriology 144, 524-531.

MALES, B. M. \& STOCKeR, B. A. D. (1982). Colicins E4, E5, E6 and $A$ and properties of btuB $B^{+}$colicinogenic transconjugants. Journal of General Microbiology 128, 95-106.

Mandel, M. \& Higa, A. (1970). Calcium-dependent bacteriophage DNA infection. Journal of Molecular Biology 53, 159-162.

Miller, J. H. (1972). Experiments in Molecular Genetics. New York: Cold Spring Harbor Laboratory.

Mock, M. \& Pugsley, A. P. (1982). The btuB group col plasmids and homology between the colicins they encode. Journal of Bacteriology 150, 1069-1076.

ØRSKOV, I. \& ØRSKOV, F. (1973). Plasmid determined $\mathrm{H}_{2} \mathrm{~S}$ character in Escherichia coli and its relation to plasmid-carried raffinose fermentation and tetracycline resistance characters. Journal of General Microbiology 77, 487-499.

Pugsley, A. \& Reeves, P. (1977). Comparison of colicins B-K60 and D-CA23: purification and characterization of the colicins and examination of colicin immunity in the producing strains. Antimicrobial Agents and Chemotherapy 11, 345-358.

Watson, R., Rowsome, W., TSAo, J. \& Vinsentin, L. P. (1981). Identification and characterization of Col plasmids from classical colicin E-producing strains. Journal of Bacteriology 147, 569-577. 